Article

\title{
Strontium Retention of Calcium Zirconium Aluminate Cement Paste Studied by NMR, XRD and SEM-EDS
}

\author{
Dominika Madej
}

Faculty of Materials Science and Ceramics, AGH University of Science and Technology, al. A. Mickiewicza 30, 30-059 Krakow, Poland; dmadej@agh.edu.pl

Received: 18 April 2020; Accepted: 19 May 2020; Published: 21 May 2020

\begin{abstract}
This work concerns the hydration mechanism of calcium zirconium aluminate as a ternary compound appearing in the $\mathrm{CaO}-\mathrm{Al}_{2} \mathrm{O}_{3}-\mathrm{ZrO}_{2}$ diagram besides the calcium aluminates commonly used as the main constitutes of calcium aluminate cements (CACs). Moreover, a state-of-the-art approach towards significant changes in hydraulic properties was implemented for the first time in this work, where the effect of structural modification on the hydration behavior of calcium zirconium aluminate was proved by XRD, ${ }^{27} \mathrm{Al}$ MAS NMR and SEM-EDS. The substitution of $\mathrm{Sr}^{2+}$ for $\mathrm{Ca}^{2+}$ in the $\mathrm{Ca}_{7} \mathrm{ZrAl}_{6} \mathrm{O}_{18}$ lattice decreases the reactivity of Sr-substituted $\mathrm{Ca}_{7} \mathrm{ZrAl}_{6} \mathrm{O}_{18}$ in the presence of water. Since the original cement grains remain unhydrated up to $3 \mathrm{~h}\left(\mathrm{Ca}_{7} \mathrm{ZrAl}_{6} \mathrm{O}_{18}\right)$ or $72 \mathrm{~h}\left(\mathrm{Sr}_{1.25} \mathrm{Ca}_{5.75} \mathrm{ZrAl}_{6} \mathrm{O}_{18}\right)$ of curing period in the hardened cement paste structures, strontium can be considered as an inhibition agent for cement hydration. The complete conversion from anhydrous ${ }^{27} \mathrm{Al}^{\mathrm{IV}}$ to hydrated ${ }^{27} \mathrm{Al}^{\mathrm{VI}}$ species was achieved during the first $24 \mathrm{~h}\left(\mathrm{Ca}_{7} \mathrm{ZrAl}_{6} \mathrm{O}_{18}\right)$ or 7 $\mathrm{d}\left(\mathrm{Sr}_{1.25} \mathrm{Ca}_{5.75} \mathrm{ZrAl}_{6} \mathrm{O}_{18}\right)$ of hydration. Simultaneously, the chemical shift in the range of octahedral aluminum from ca. $4 \mathrm{ppm}$ to ca. $6 \mathrm{ppm}$ was attributed to the transformation of the hexagonal calcium aluminate hydrates and Sr-rich $(\mathrm{Sr}, \mathrm{C})_{3} \mathrm{AH}_{6}$ hydrate into the cubic phase Ca-rich $(\mathrm{Sr}, \mathrm{C})_{3} \mathrm{AH}_{6}$ or pure $\mathrm{C}_{3} \mathrm{AH}_{6}$ in the hardened Sr-doped cement paste at the age of $7 \mathrm{~d}$. The same ${ }^{27} \mathrm{Al} \mathrm{NMR}$ chemical shift was detected at the age of $24 \mathrm{~h}$ for the reference hardened undoped $\mathrm{Ca}_{7} \mathrm{ZrAl}_{6} \mathrm{O}_{18}$ cement paste.
\end{abstract}

Keywords: $\mathrm{Ca}_{7} \mathrm{ZrAl}_{6} \mathrm{O}_{18} ;{ }^{27} \mathrm{Al}$ MAS NMR; Sr-rich $(\mathrm{Sr}, \mathrm{C})_{3} \mathrm{AH}_{6}$; cement hydration; refractories; immobilization of radioactive $\mathrm{Sr}$

\section{Introduction}

Calcium aluminate cements (CACs) [1-3] and other related cementitious systems [4-7] are believed to play an important role in a wide range of specialist are as from some construction areas and civil engineering, to refractory materials industry, due to their ability to gain strength rapidly in the initial days after casting and to withstand aggressive environments and high temperatures. The temperature-time weight ratio of water-to-cement (the w/c ratio) dependencies of the cement hydration processes have been widely investigated so far and are presented elsewhere in detail [8-10]. It must be made clear at this stage that both temperature and a weight ratio of water-to-cement (the $\mathrm{w} / \mathrm{c}$ ratio) affect the performances of calcium aluminate cements, especially at an early age. The phase composition, microstructure and other properties of the cement pastes can easily be designed by choosing appropriate curing parameters. Nevertheless, upon curing of CAC-based paste at not adequately controlled, ambient conditions, these materials are very sensitive to humidity, $\mathrm{CO}_{2}$, temperature and time. Due to the fact of not being able to predict their long-term behavior makes them practically not suitable for constructions but suitable for building chemistry. Nevertheless, the high-early-heat and high-early-strength gain makes CACs attractive, especially in the winter 
months and/or when rapid repairs are needed. The hydration product formation in CACs containing mainly monocalcium aluminate $\left(\mathrm{CaAl}_{2} \mathrm{O}_{4} ; \mathrm{CA}\right)$ and monocalcium di aluminate $\left(\mathrm{CaAl}_{4} \mathrm{O}_{7} ; \mathrm{CA}_{2}\right)$ is characterized by the dependence of $\mathrm{C}-\mathrm{A}-\mathrm{H}^{*}\left(\mathrm{C}=\mathrm{CaO}, \mathrm{A}=\mathrm{Al}_{2} \mathrm{O}_{3}, \mathrm{H}=\mathrm{H}_{2} \mathrm{O}\right)$ phases on temperature. At a temperature below ca. $15^{\circ} \mathrm{C}$, calcium aluminates are hydrated to form metastable $\mathrm{CAH}_{10}$. At room temperature, the hydration process proceeds through the formation of other metastable phases $\mathrm{C}_{2} \mathrm{AH}_{8}$ and/or $\mathrm{C}_{4} \mathrm{AH}_{13-19}$ (hexagonal hydrates). At higher temperatures (above $28^{\circ} \mathrm{C}$ ), the metastable hydrates will spontaneously convert to the cubic hydrogarnet $\mathrm{C}_{3} \mathrm{AH}_{6}$. Furthermore, according to insights into hydration of CACs, the hydration products during long hydration shall be presented as follows: $\mathrm{C}_{3} \mathrm{AH}_{6}+\mathrm{AH}_{3}$. The 10-year results, which have been added to existing results on the hydration of calcium aluminate compounds, are of interest as showing the $\mathrm{CaO}-\mathrm{Al}_{2} \mathrm{O}_{3}-\mathrm{ZrO}_{2}[4,6,11]$ as an interesting alternative to CACs-based materials. This can be attributed to the fact, that this category of special cement which contains both hydraulic phases (CA, $C_{2}, C_{12} A_{7}$ and $C_{7} A_{3} Z^{*}$ ), and $Z r$-bearing compounds ( $\mathrm{CZ}$ and $\mathrm{Z}$ ) [4] is synthesized by one environmentally friendly and effective technological process. This fact makes the attention-getter of a C-A-Z cements' users more important than those of other CACs users and worth considering from the point of view of economics. The principal interest here is concerned with the $\mathrm{C}_{7} \mathrm{~A}_{3} \mathrm{Z}$ area including crystal structure, hydration behavior of $\mathrm{C}_{7} \mathrm{~A}_{3} \mathrm{Z}$ and its solid solutions with $\mathrm{SrO}$ and $\mathrm{BaO}$, hydration products and carbonation processes in cement paste structures [12,13]. Special interest was given to strontium. Because strontium is chemically closely related to calcium, it is easily introduced as a natural substitute for calcium in aluminate phases. Strontium has been shown to affect the hydration behavior of calcium zirconium aluminate cement $[5,13]$. Furthermore, strontium-containing cements attract the attention of materials scientists due to their higher refractory properties, increased resistance to thermal shock, increased resistance to chemical aggressive solutions and possible applications as special binders for shielding constructions in nuclear power plants [14]. Although this approach is unique, there are other approaches to affecting the hydration behavior of aluminates-bearing CACs and related materials. Results from other studies indicate that the metal chloride and nitrate salts are known in CAC science as agents affecting the CAC hydration behavior $[15,16]$. The exact nature of this behavior is different for alkali metal salts $(\mathrm{NaCl}$, $\mathrm{KCl}, \mathrm{RbCl}, \mathrm{CsCl}, \mathrm{LiCl})$, alkaline earth metal salts $\left(\mathrm{MgCl}_{2} \cdot 6 \mathrm{H}_{2} \mathrm{O}, \mathrm{CaCl}_{2}, \mathrm{SrCl}_{2} \cdot 6 \mathrm{H}_{2} \mathrm{O}\right.$ and $\left.\mathrm{BaCl}_{2} \cdot 2 \mathrm{H}_{2} \mathrm{O}\right)$ and transition metal salts $\left(\mathrm{MnCl}_{2} \cdot \mathrm{H}_{2} \mathrm{O}, \mathrm{CoCl}_{2} \cdot 6 \mathrm{H}_{2} \mathrm{O}, \mathrm{CuCl}_{2} \cdot 2 \mathrm{H}_{2} \mathrm{O}\right.$ and $\left.\mathrm{ZnCl}_{2}\right)$. Generally, the addition of alkali metal salts accelerates the setting time of $\mathrm{CAC}$, whereas the transition metal salts can be widely used as retarders. The effect of alkaline earth metal salts on setting the behavior of CAC is determined by the amount of addition [15]. Another approach in the acceleration effect is the addition of chlorides and nitrates of $\mathrm{Li}(\mathrm{I}), \mathrm{Cr}(\mathrm{III}), \mathrm{Zn}(\mathrm{II})$ and $\mathrm{Cr}(\mathrm{VI})$ (chromate), whereas $\mathrm{Pb}(\mathrm{II})$ and $\mathrm{Cu}(\mathrm{II})$ retarded the hydration [16].

Many various techniques including XRD, FT-IR, Raman spectroscopy, DSC-TG-EGA(MS), SEM-EDS, isothermal calorimetry and EIS were being accepted in this research. It is also well known that solid-state nuclear magnetic resonance (ssNMR) spectroscopy is an effective tool for the characterization of cement paste at the atomic scale in different stages of its aging. The application of NMR to monitor the progress of CACs hydration has a long history and can be found elsewhere [17-20]. In cement chemistry, four-fold coordinated (tetrahedral) ${ }^{\mathrm{IV}} \mathrm{Al}$ sites and six-fold coordinated (octahedral) ${ }^{\mathrm{VI}} \mathrm{Al}$ sites typically resonate within the regions 50-80 ppm and 0-20 ppm, respectively. The resonances assigned to five-coordinated $\mathrm{V}^{\mathrm{Al}}$ and highly distorted tetrahedral Al environments have been observed in the region 20-50 ppm [18,21,22]. For example, the ${ }^{27}$ Al MAS NMR spectrum of CA shows a peak maximum at ca. $80 \mathrm{ppm}$ and a shoulder at $76 \mathrm{ppm}$ due to six crystal ographically different aluminum tetrahedral sites [19,23-25]. For another example, the ${ }^{27}$ Al MAS NMR spectrum of $\mathrm{CA}_{2}$ exhibits the peaks between 50 and 75 ppm due to the two distinct ${ }^{27} \mathrm{Al}$ environments $[18,25]$. On the other hand, calcium aluminate hydrates $\left(\mathrm{CAH}_{10}, \mathrm{C}_{2} \mathrm{AH}_{8}, \mathrm{C}_{4} \mathrm{AH}_{13-19}, \mathrm{C}_{3} \mathrm{AH}_{6}\right)$, originating from the hydration process of $\mathrm{CAC}$ clinker phases, are octahedrally coordinated $\mathrm{Al}(\mathrm{OH})_{6}$ and cause a ${ }^{27} \mathrm{Al}$ MAS NMR signal at about 0 ppm. Hence, ${ }^{27}$ Al MAS NMR provides the relative changes of tetrahedral and octahedral Al sites of the hydrating cement paste at different stages of the curing. The resonance position from an octahedral 
${ }^{27} \mathrm{Al}$ NMR signal varies slightly depending on the types of calcium aluminate hydrates present [19]. The resonance at ca. $12.36 \mathrm{ppm}$ is due to tricalcium aluminate hexahydrate $\mathrm{C}_{3} \mathrm{AH}_{6}[18,20]$, at ca. 10.2 ppm due to $\mathrm{CAH}_{10}$ and $\mathrm{C}_{4} \mathrm{AH}_{13}$ [18-20] and at ca. 10.3 ppm due to $\mathrm{C}_{2} \mathrm{AH}_{8}$ [17].

The aim of this work is to implement the NMR technique to monitor the progress of hydration of both undoped- and strontium-doped calcium zirconium aluminate cement. Hence, the influence of structural modification with $\mathrm{SrO}$ on the hydraulic activity of $\mathrm{Ca}_{7} \mathrm{ZrAl}_{6} \mathrm{O}_{18}$ phase has been demonstrated. This work fills in a significant gap in the literature on the exploiting ssNMR spectroscopy to probe the early stages of hydration of new types of cements belonging to the $\mathrm{CaO}-\mathrm{Al}_{2} \mathrm{O}_{3}-\mathrm{ZrO}$ and $\mathrm{CaO}-\mathrm{SrO}-\mathrm{Al}_{2} \mathrm{O}_{3}-\mathrm{ZrO}_{2}$ systems.

\section{Experimental Procedure}

\subsection{Synthesis and Phase Identification}

Low-cost synthesis of $\mathrm{Ca}_{7} \mathrm{ZrAl}_{6} \mathrm{O}_{18}, \mathrm{Sr}_{1.25} \mathrm{Ca}_{5.75} \mathrm{Al}_{6} \mathrm{O}_{18}$ and $\mathrm{SrAl}_{2} \mathrm{O}_{4}$ cements via the solid-state reactive sintering technique was employed using the stoichiometric amount of the cationic ratios of $\mathrm{Ca}: \mathrm{Zr}: \mathrm{Al}=$ 7:1:6, Sr:Ca:Zr:Al = 1.25:5.75:1:6 and Sr:Al = 1:2, respectively. Strontium was incorporated into $\mathrm{Ca}_{7} \mathrm{ZrAl}_{6} \mathrm{O}_{18}$ by replacing 1.25 atoms of calcium, since the maximum level of doping was experimentally established. Both $\mathrm{Ca}_{7} \mathrm{ZrAl}_{6} \mathrm{O}_{18}$ and $\mathrm{SrAl}_{2} \mathrm{O}_{4}$ cements were synthesized as reference materials to obtain pure $\mathrm{C}-\mathrm{A}-\mathrm{H}$ and $\mathrm{Sr}-\mathrm{A}-\mathrm{H}$ phases. Starting raw materials were reagent-grade $\mathrm{CaCO}_{3}$ (99.9\%, $\mathrm{POCH}$ ), $\mathrm{SrCO}_{3}$ (98.0\%, Merck), $\mathrm{Al}_{2} \mathrm{O}_{3}$ (99.0\%, Acros Organics) and $\mathrm{ZrO}_{2}$ (98.5\%, Acros Organics). The $100 \mathrm{~g}$ mixtures of substrates were homogenized for $2 \mathrm{~h}$, pressed into cylindrical pellets at pressures of $50 \mathrm{MPa}$ and calcined at $1000^{\circ} \mathrm{C}$ for $10 \mathrm{~h}$ (Sr-free sample) or at $1300^{\circ} \mathrm{C}$ for $10 \mathrm{~h}$ (Sr-containing samples) in air. Phase pure cement clinker minerals were made from mixtures of prereacted powders via grinding, pressing and sintering at $1420{ }^{\circ} \mathrm{C}\left(\mathrm{Ca}_{7} \mathrm{ZrAl}_{6} \mathrm{O}_{18}\right.$ and $\left.\mathrm{Sr}_{1.25} \mathrm{Ca}_{5.75} \mathrm{Al}_{6} \mathrm{O}_{18}\right)$ and $1550{ }^{\circ} \mathrm{C}$ $\left(\mathrm{SrAl}_{2} \mathrm{O}_{4}\right)$ for $20 \mathrm{~h}$ in air.

Phase identification for the sintered samples was carried out using X-ray diffraction (XRD, PANalytical, Malvern PANalytical, Malvern, UK) on a ProPANalytical X'Pert X-ray diffractometer, with $\mathrm{Cu} K \alpha$ radiation $(\lambda=0.15418 \mathrm{~nm})$, with $0.02^{\circ}$ per step and 3 s time per step (2theta range from $5^{\circ}$ to $45^{\circ}$ ).

The NMR spectra were recordedat room temperature on Bruker Avance III 400WB (9.4T) spectrometer, (Bruker BioSpin, Rheinstetten, Germany) using 4 mm MAS (Magic Angle Spinning), dual-channel $(1 \mathrm{H} / \mathrm{BB})$ probe-head, operating at a resonance frequency of $104.26 \mathrm{MHz}$ for ${ }^{27} \mathrm{Al}$. The sample was spun at a MAS frequency of $8 \mathrm{kHz}$ in the rotors made of zirconium dioxide $(4 \mathrm{~mm})$. $32 \mathrm{~K}$ data points and 1024 scans FIDs were accumulated with a Single Pulse Excitation (SPE) pulse sequence using the observed $90^{\circ}$ pulse $\left({ }^{27} \mathrm{Al}\right)$ set at 6.0 us with a relaxation delay of $200 \mathrm{~ms}$. Note no proton decoupling was applied during the experiment. Prior to Fourier transformation, the data were zero-filled twice and $80 \mathrm{~Hz}$ apodization filter was applied. The ${ }^{27} \mathrm{Al}$ chemical shifts were referenced using a sample of $\mathrm{AlCl}_{3} \cdot 6 \mathrm{H}_{2} \mathrm{O}$ in $1 \mathrm{M}$ solution as an external reference $(0 \mathrm{ppm})$.

The microstructures of fracture surfaces of hydrated cement pastes were investigated using a scanning electron microscope (SEM, FEI Nova Nano SEM 200, Kyoto, Japan.). The chemical compositions of the samples were determined with electron-probe microanalysis using an energy-dispersive X-ray spectrometer (EDAX, Sapphire Si(Li) EDS detector, Mahwah, NJ, USA).

\subsection{Preparation and Treatment of Cement Paste}

Comparison study of hydration characteristics between $\mathrm{Ca}_{7} \mathrm{ZrAl}_{6} \mathrm{O}_{18}, \mathrm{Sr}_{1.25} \mathrm{Ca}_{5.75} \mathrm{Al}_{6} \mathrm{O}_{18}$ and $\mathrm{SrAl}_{2} \mathrm{O}_{4}$ cements were determined for cement pastes prepared with water-to-cement $(\mathrm{w} / \mathrm{c})$ ratios of 1.0 or 0.5 . The water-to-cement ratio of 0.5 was applied to achieve plastic properties without any undesirable sedimentation of neat $\mathrm{SrAl}_{2} \mathrm{O}_{4}$ paste. Whereas, both $\mathrm{Ca}_{7} \mathrm{ZrAl}_{6} \mathrm{O}_{18}$ and $\mathrm{Sr}_{1.25} \mathrm{Ca}_{5.75} \mathrm{Al}_{6} \mathrm{O}_{18}$ cements require $\mathrm{w} / \mathrm{c}=1.0$ to obtain the well-homogenized cement pastes without any undesirable phenomena of sedimentation. The cement powders which were obtained by grinding the sintered 
pellets and necessary mass of water were mixed together in a glass beaker to obtain three homogeneous neat cement pastes. Each neat cement paste was then placed in a polyethylene bag and sealed until $14 \mathrm{~d}$ at $50{ }^{\circ} \mathrm{C}$. According to Litwinek and Madej [5], the optimal synthesis temperature for $\mathrm{C}_{3} \mathrm{AH}_{6}$ from different precursors through hydration is suggested to be $50^{\circ} \mathrm{C}$. Moreover, this period for curing cement pastes was accepted to attain the maximum degree of hydration, as concluded from the previous studies [13]. Moreover, as it was previously mentioned by Garcés et al. [26] and Zhang et al. [27], at temperatures as high as $60^{\circ} \mathrm{C}$, only the cubic phase and the gibbsite appear in the calcium aluminates-based cement pastes. At $24 \mathrm{~h}$ and $7 \mathrm{~d}$, the microstructure of cement pastes was investigated by SEM. Acetone quenching was used to stop hydration at $15 \mathrm{~min}, 0.5 \mathrm{~h}, 1 \mathrm{~h}, 2 \mathrm{~h}, 3 \mathrm{~h}, 24 \mathrm{~h}, 48 \mathrm{~h}, 72 \mathrm{~h}, 7 \mathrm{~d}$ and $14 \mathrm{~d}$ (Table 1). The use of cold acetone, aiming to withdraw free water and inhibit further reactions within cement paste is known from the Ref. [28]. Cold acetone is related to acetone stored under laboratory conditions. Quenched pastes were characterized by XRD and ${ }^{27} \mathrm{Al}$ MAS NMR (Bruker BioSpin, Rheinstetten, Germany), according to the procedures presented in Section 2.1.

Table 1. Cement paste formulations, curing conditions and details of sample designation.

\begin{tabular}{|c|c|c|c|}
\hline Sample Designation & Cement/Sample & Hydration Time & $\begin{array}{l}\text { Water-to-Cement Ratio } \\
\text { (w/c), Temperature }\end{array}$ \\
\hline A & $\begin{array}{c}\mathrm{Sr}_{1.25} \mathrm{Ca}_{5.75} \mathrm{ZrAl}_{6} \mathrm{O}_{18}(\text { as a solid } \\
\text { solution) }\end{array}$ & $\begin{array}{c}15 \mathrm{~min}, 0.5 \mathrm{~h}, 1 \mathrm{~h}, 2 \mathrm{~h}, 3 \mathrm{~h}, \\
24 \mathrm{~h}, 48 \mathrm{~h}, 72 \mathrm{~h}, 7 \mathrm{~d} \text { and } \\
14 \mathrm{~d}\end{array}$ & $\mathrm{w} / \mathrm{c}=1.0, \mathrm{~T}=50^{\circ} \mathrm{C}$ \\
\hline B & $\begin{array}{l}\mathrm{SrAl}_{2} \mathrm{O}_{4} \text { (as a reference } \\
\text { undoped compound })\end{array}$ & $7 \mathrm{~d}$ & $\mathrm{w} / \mathrm{c}=0.5, \mathrm{~T}=50^{\circ} \mathrm{C}$ \\
\hline $\mathrm{C}$ & $\begin{array}{l}\mathrm{Ca}_{7} \mathrm{ZrAl}_{6} \mathrm{O}_{18} \text { (as a reference } \\
\text { undoped compound) }\end{array}$ & $\begin{array}{c}15 \mathrm{~min}, 0.5 \mathrm{~h}, 1 \mathrm{~h}, 2 \mathrm{~h}, 3 \mathrm{~h}, \\
24 \mathrm{~h}, 48 \mathrm{~h}, 72 \mathrm{~h}, 7 \mathrm{~d} \text { and } \\
14 \mathrm{~d}\end{array}$ & $\mathrm{w} / \mathrm{c}=1.0, \mathrm{~T}=50^{\circ} \mathrm{C}$ \\
\hline
\end{tabular}

\section{Results and Discussion}

\subsection{X-ray Diffraction Analysis of Special Cements Hydration}

According to X-ray diffraction analysis, the cement clinkers synthesized by the solid-state reactive sintering technique were all crystalline, single-phase aluminate phases $\mathrm{Ca}_{7} \mathrm{ZrAl}_{6} \mathrm{O}_{18}$, $\mathrm{Sr}$-doped $\mathrm{Ca}_{7} \mathrm{ZrAl}_{6} \mathrm{O}_{18}$ and $\mathrm{SrAl}_{2} \mathrm{O}_{4}$. The positions of the characteristic diffraction peaks in the XRD patterns of the $\mathrm{Ca}_{7} \mathrm{ZrAl}_{6} \mathrm{O}_{18}$ (Sample C) and $\mathrm{SrAl}_{2} \mathrm{O}_{4}$ (Sample B) cement clinkers have a strong agreement with the standards JCPDS No. 98-018-2622 and JCPDS No. 98-016-0296, respectively. This confirms that the powders are mainly composed of $\mathrm{Ca}_{7} \mathrm{ZrAl}_{6} \mathrm{O}_{18}$ and $\mathrm{SrAl}_{2} \mathrm{O}_{4}$, respectively. As expected, the slight shift in diffraction peaks towards lower $2 \theta$ value in the XRD pattern of $\mathrm{Sr}_{1.25} \mathrm{Ca}_{5.75} \mathrm{ZrAl}_{6} \mathrm{O}_{18}$ cement clinker confirms an increase in lattice parameter of Sr-doped $\mathrm{Ca}_{7} \mathrm{ZrAl}_{6} \mathrm{O}_{18}$ solid solution. Since no secondary phases containing $\mathrm{Sr}$ were detected, Sr was recognized as fully incorporated into the $\mathrm{Ca}_{7} \mathrm{ZrAl}_{6} \mathrm{O}_{18}$ structure.

Compared with the XRD patterns of unhydrated phases, the decreasing intensity of peaks corresponding to $\mathrm{Sr}_{1.25} \mathrm{Ca}_{5.75} \mathrm{ZrAl}_{6} \mathrm{O}_{18}$ and $\mathrm{Ca}_{7} \mathrm{ZrAl}_{6} \mathrm{O}_{18}$, and new peaks of low intensity corresponding to hydration products formation were recorded using XRD (Figures 1-3). A low degree of hydrates crystallinity was indicated by a poor XRD pattern, especially in the early stage of hydration. Moreover, the hydration processes result in a corresponding change in the XRD patterns of the initial cement clinker phases and formation of amorphous material, besides the crystalline hydrates, as it can be concluded from the severe intensity reduction and peaks broadening in the XRD pattern. 


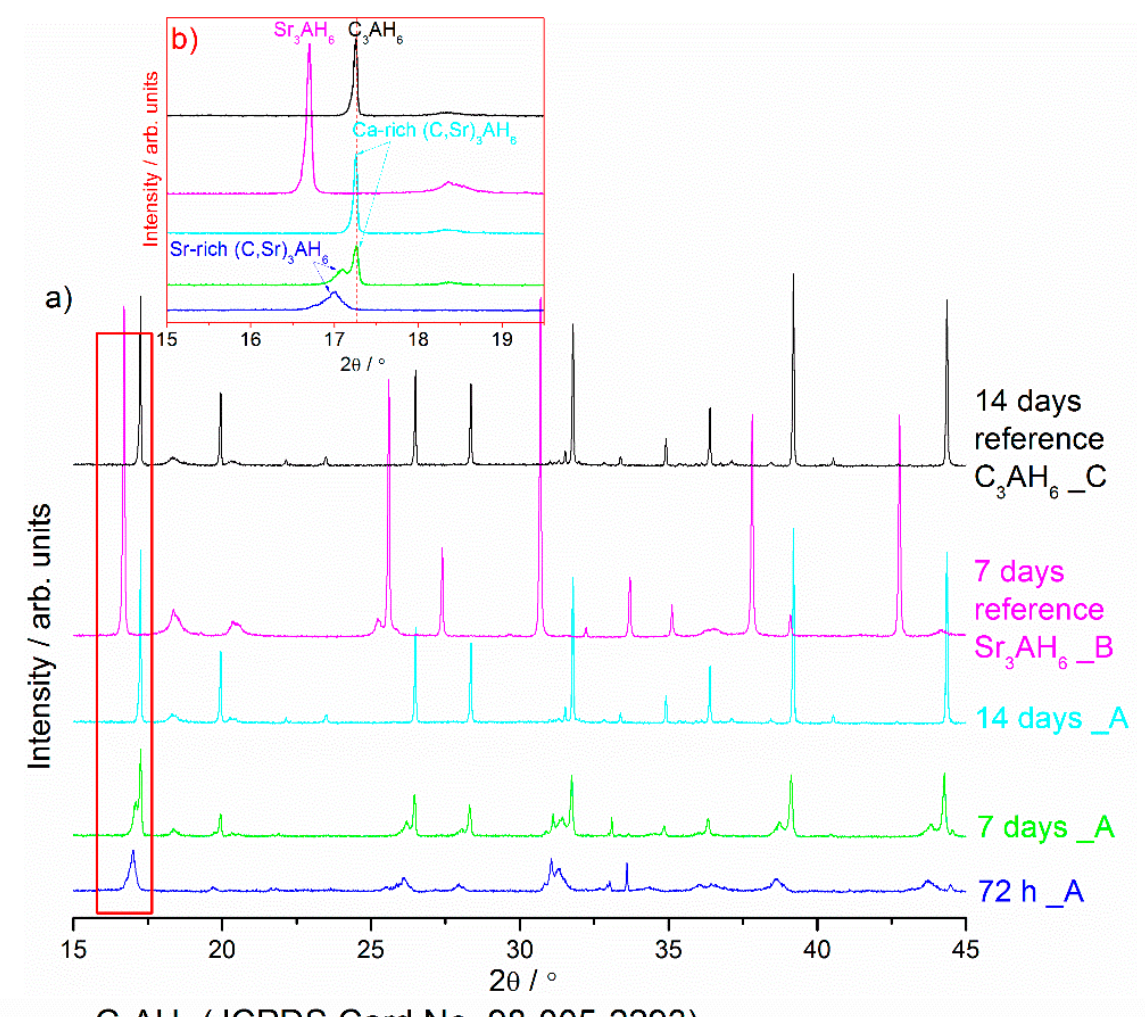

$\mathrm{C}_{3} \mathrm{AH}_{6}$ (JCPDS Card No. 98-005-2293)

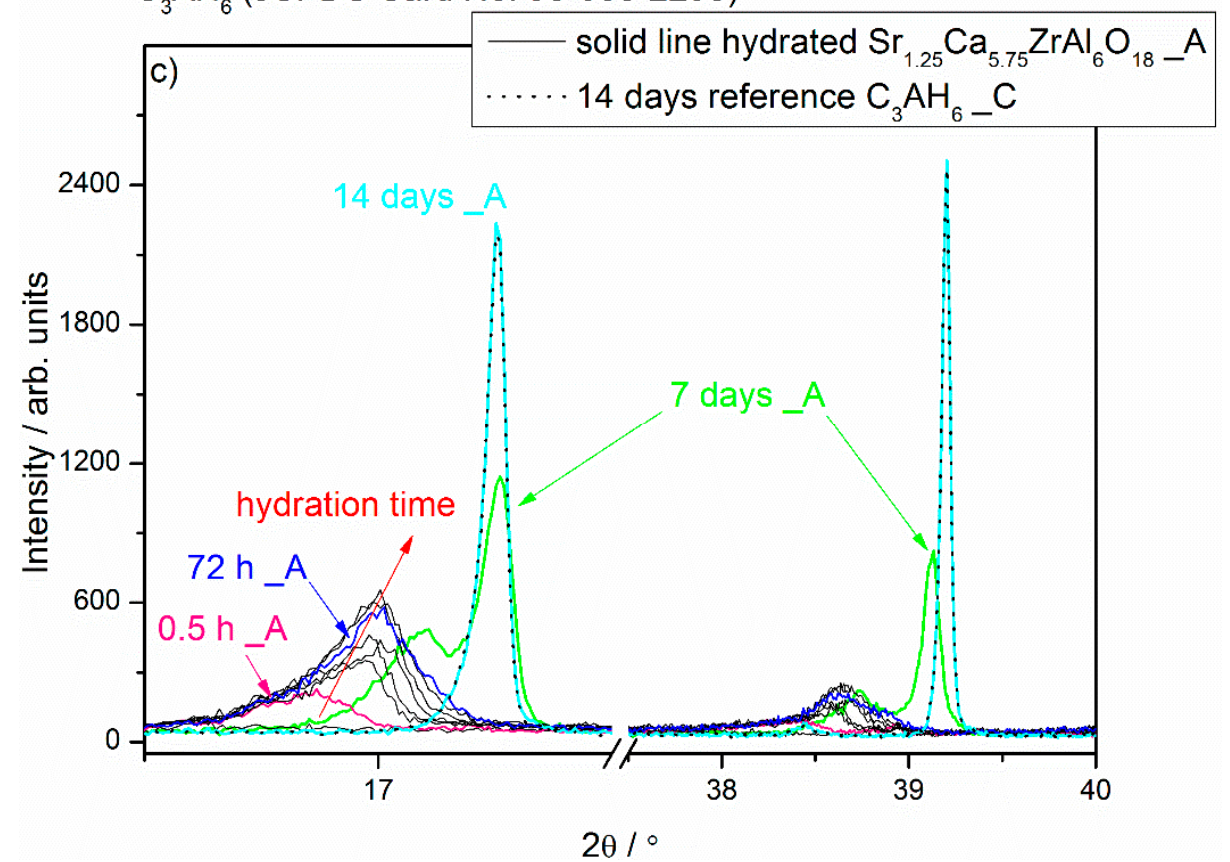

Figure 1. X-ray diffraction patterns of the $\mathrm{Sr}_{1.25} \mathrm{Ca}_{5.75} \mathrm{ZrAl}_{6} \mathrm{O}_{18}$ cement paste (Sample A) at different curing periods. $(\mathbf{a}, \mathbf{b})$ contains lines of two reference materials, i.e., $\mathrm{Sr}_{3} \mathrm{AH}_{6}$ synthesized through hydration from $\mathrm{SrAl}_{2} \mathrm{O}_{4}$ cement (Sample B) and $\mathrm{C}_{3} \mathrm{AH}_{6}$ synthesized through hydration from $\mathrm{Ca}_{7} \mathrm{ZrAl}_{6} \mathrm{O}_{18}$ cement (Sample C). (c) contains a line (dot line) of the reference $\mathrm{C}_{3} \mathrm{AH}_{6}$ formed at $14 \mathrm{~d}$ (Sample C). 


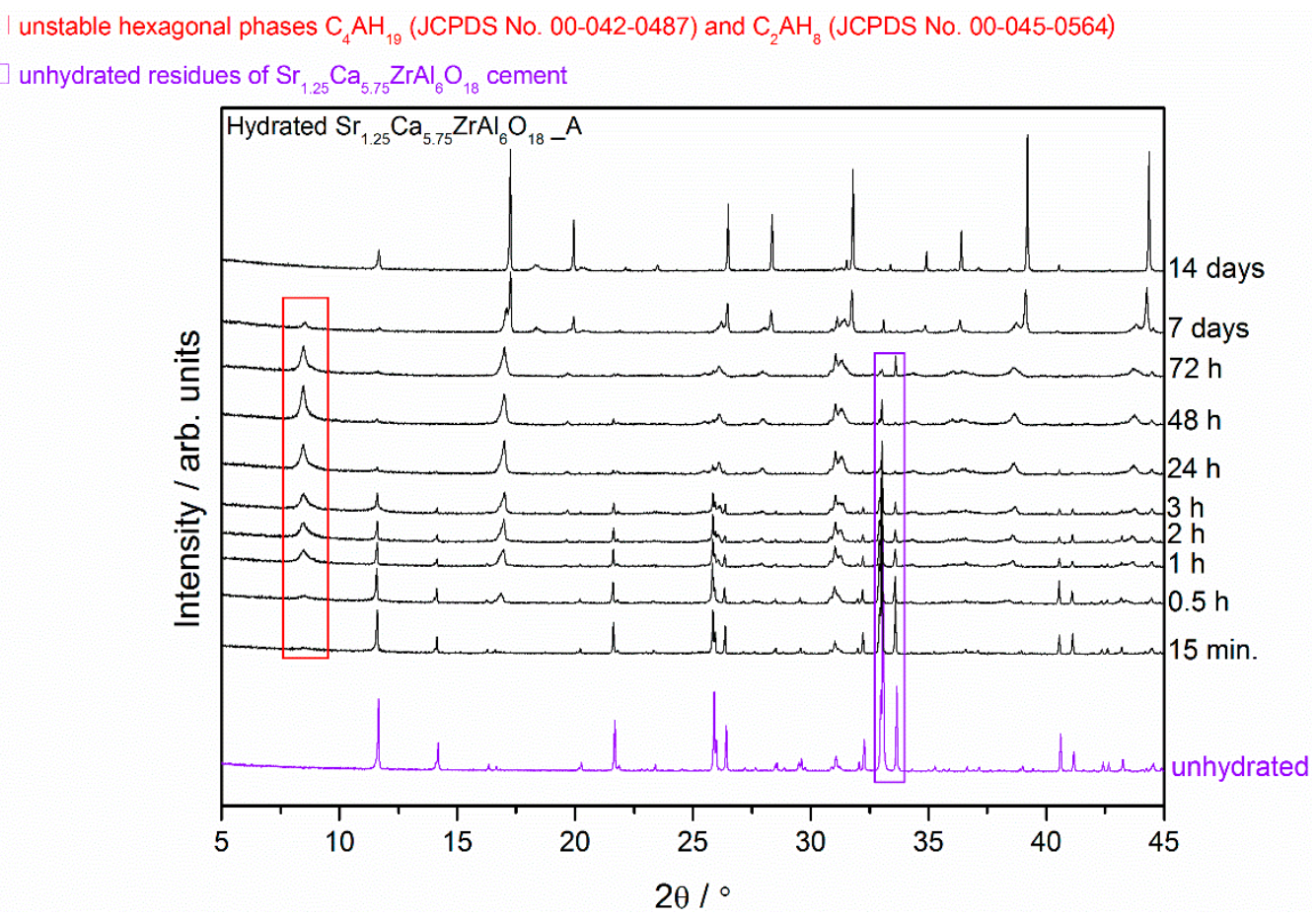

Figure 2. X-ray diffraction patterns of the $\mathrm{Sr}_{1.25} \mathrm{Ca}_{5.75} \mathrm{ZrAl}_{6} \mathrm{O}_{18}$ cement paste (Sample A) at different curing periods from $15 \mathrm{~min}$ to $14 \mathrm{~d}$ compared with the XRD pattern of the unhydrated compound.

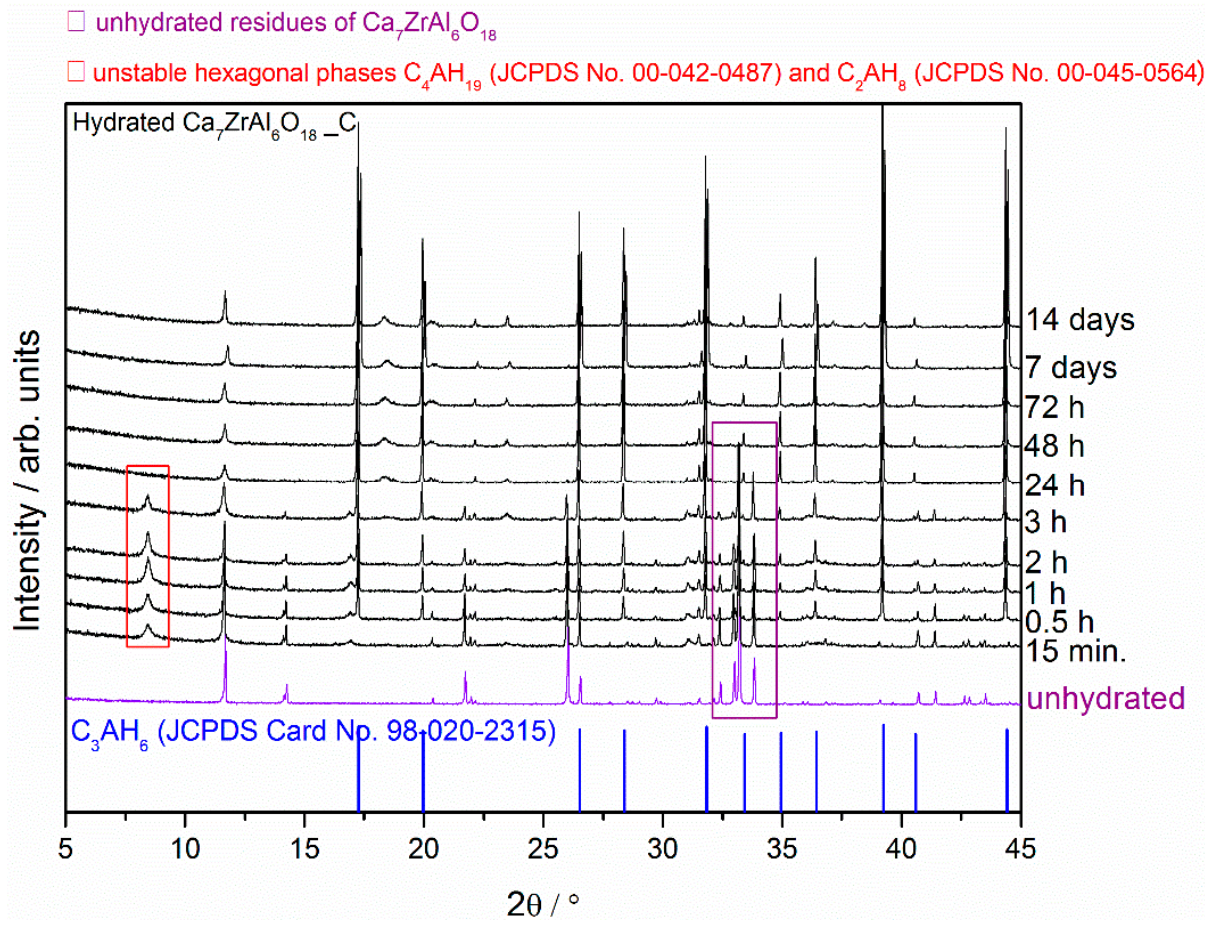

Figure 3. X-ray diffraction patterns of the $\mathrm{Ca}_{7} \mathrm{ZrAl}_{6} \mathrm{O}_{18}$ cement paste (Sample $\mathrm{C}$ ) at different curing periods from $15 \mathrm{~min}$ to $14 \mathrm{~d}$ compared with the XRD pattern of the unhydrated compound.

The results of powder X-ray diffraction patterns evaluation show the progress of $\mathrm{Sr}_{1.25} \mathrm{Ca}_{5.75} \mathrm{ZrAl}_{6} \mathrm{O}_{18}$ hydration in cement paste between $15 \mathrm{~min}$ and $14 \mathrm{~d}$ of curing which are more or less similar at an early stage of hydration (up to $72 \mathrm{~h}$ ) Figure $1 \mathrm{a}-\mathrm{c}$. The XRD profiles of the cement pastes hydrated between 0.5 and $72 \mathrm{~h}$ demonstrate diffraction peak at ca. $17.00^{\circ} 2 \theta$ which can now be interpreted as belonging to $\mathrm{Sr}$-rich $(\mathrm{Sr}, \mathrm{C})_{3} \mathrm{AH}_{6}$ hydrate (Figure 1c). Hence, this XRD peak located at the position of $2 \theta=17.00$ which belongs to $\mathrm{Sr}$-rich $(\mathrm{Sr}, \mathrm{C})_{3} \mathrm{AH}_{6}$ needs to be considered between the 
reference $\mathrm{C}_{3} \mathrm{AH}_{6}$ synthesized through $\mathrm{Ca}_{7} \mathrm{ZrAl}_{6} \mathrm{O}_{18}$ hydration and other reference sample $\mathrm{Sr}_{3} \mathrm{AH}_{6}$ synthesized from $\mathrm{SrAl}_{2} \mathrm{O}_{4}$ precursor through hydration. As is evident from this figure, the formation of the intermediate $\mathrm{Sr}$-rich $(\mathrm{Sr}, \mathrm{C})_{3} \mathrm{AH}_{6}$ hydrate precedes the formation of the stable Ca-rich $(\mathrm{Sr}, \mathrm{C})_{3} \mathrm{AH}_{6}$ hydrate at $7 \mathrm{~d}$ of curing. In this sample, two isostructural compounds with a hydrogarnet type crystal lattice were present. The position of the lower-intensity XRD line at ca. $17.00^{\circ} 2 \theta$ is situated between lines belonging to pure phases $\mathrm{Sr}_{3} \mathrm{AH}_{6}$ (Sample B) and $\mathrm{C}_{3} \mathrm{AH}_{6}$ (Sample C). The second position of the higher intensity XRD line at ca. $17.26^{\circ} 2 \theta$ is similar to that found for reference $\mathrm{C}_{3} \mathrm{AH}_{6}$ (Figure 1a-c). In addition, it is worth noting that the $\mathrm{Sr}$-rich $(\mathrm{Sr}, \mathrm{C})_{3} \mathrm{AH}_{6}$ exists in the hardened cement paste between $0.5 \mathrm{~h}$ and $7 \mathrm{~d}$ of curing. This phase disappeared after longer curing times and became replaced by Ca-rich $(\mathrm{Sr}, \mathrm{C})_{3} \mathrm{AH}_{6}$ or $\mathrm{C}_{3} \mathrm{AH}_{6}$. This work has successfully shown the existence of the solid solution of strontium in the tricalcium hydrate $\mathrm{C}_{3} \mathrm{AH}_{6}$ lattice by direct verification using XRD. By reason of structural modification of $\mathrm{C}_{3} \mathrm{AH}_{6}$ through ionic substitution, the lattice parameter of the cubic phase was increased and the slight shift in XRD peaks belonging to $(\mathrm{Sr}, \mathrm{C})_{3} \mathrm{AH}_{6}$ solid solution towards lower $2 \theta$ value was observed (Figure $1 \mathrm{~b}$ ). This increase in the lattice parameter was due to the size of the ionic radius of $\mathrm{Sr}^{2+}(132 \mathrm{pm})$ which is bigger than the ionic radius of $\mathrm{Ca}^{2+}(114 \mathrm{pm})$.

A brief summary of XRD results is given as Figures 2 and 3. This overview XRD spectra recorded from the $\mathrm{Sr}_{1.25} \mathrm{Ca}_{5.75} \mathrm{ZrAl}_{6} \mathrm{O}_{18}$ cement paste (Sample A) at different curing periods from $15 \mathrm{~min}$ to $14 \mathrm{~d}$ showed a progressive reduction in the peaks associated with $\mathrm{Sr}_{1.25} \mathrm{Ca}_{5.75} \mathrm{ZrAl}_{6} \mathrm{O}_{18}$ due to its hydration process, which led to the formation of hydration products (Figure 2). The cement paste at the age of $15 \mathrm{~min}$ is a mixture of the unhydrated phase and amorphous or poorly crystalline hexagonal hydrates, whereas the cement paste at the age between $0.5 \mathrm{~h}$ and $72 \mathrm{~h}$ contained a mixture of the Sr-rich $(\mathrm{Sr}, \mathrm{C})_{3} \mathrm{AH}_{6}$ cubic phase, hexagonal hydrates and the still unhydrated residues of the $\mathrm{Sr}_{1.25} \mathrm{Ca}_{5.75} \mathrm{ZrAl}_{6} \mathrm{O}_{18}$ cement grains. It should be noted that the positions of the XRD peaks of $\mathrm{C}_{4} \mathrm{AH}_{19}$ (JCPDS No. 00-042-0487; h k l = $006, \mathrm{~d}=10.64350 \AA, 2 \theta=8.301^{\circ}, \mathrm{I}=100 \%$ ) are coincident well with those belonging to $\mathrm{C}_{2} \mathrm{AH}_{8}$ (JCPDS No. 00-045-0564, h k l $=006, \mathrm{~d}=10.81270 \AA 2,2 \theta=8.170^{\circ}, \mathrm{I}=100 \%$ ). Therefore, it is often difficult to clearly differentiate between $\mathrm{C}_{4} \mathrm{AH}_{19}$ and $\mathrm{C}_{2} \mathrm{AH}_{8}$ in the XRD patterns, as is clearly demonstrated with a red rectangle $(\square)$ in Figure 2 . However, at $7 \mathrm{~d}$ second adjacent cubic phase, Ca-rich $(\mathrm{Sr}, \mathrm{C})_{3} \mathrm{AH}_{6}$ or pure $\mathrm{C}_{3} \mathrm{AH}_{6}$, exists together with the initially formed cubic phase $\mathrm{Sr}$-rich $(\mathrm{Sr}, \mathrm{C})_{3} \mathrm{AH}_{6}$ and some residues of the hexagonal hydrates. As a general trend at the age of $14 \mathrm{~d}, \mathrm{XRD}$ pattern of cement paste achieved profile similar to that of pure $\mathrm{C}_{3} \mathrm{AH}_{6}$ (Figures 1c and 2) without any metastable hydrates and unhydrated cement residues, i.e., unhydrated cement clinker mineral $\mathrm{Sr}_{1.25} \mathrm{Ca}_{5.75} \mathrm{ZrAl}_{6} \mathrm{O}_{18}$.

The overview XRD spectra recorded from the reference $\mathrm{Ca}_{7} \mathrm{ZrAl}_{6} \mathrm{O}_{18}$ cement paste (Sample C) at different curing periods from $15 \mathrm{~min}$ to $14 \mathrm{~d}$ is shown in Figure 3. The hexagonal hydrates exist with the still unhydrated residues of the $\mathrm{Ca}_{7} \mathrm{ZrAl}_{6} \mathrm{O}_{18}$ in cement paste between $15 \mathrm{~min}$ and $3 \mathrm{~h}$ of curing period, whereas $\mathrm{C}_{3} \mathrm{AH}_{6}$ hydrated phase is formed at the curing age of $0.5 \mathrm{~h}$. At the age of $24 \mathrm{~h}$, the XRD pattern of the cement pastes exhibits profile similar to that of pure $\mathrm{C}_{3} \mathrm{AH}_{6}$ without any traces of unhydrated cement particles $\mathrm{Ca}_{7} \mathrm{ZrAl}_{6} \mathrm{O}_{18}$ and metastable hydrates.

From the $\mathrm{X}$-ray diffraction results, it seems obvious that strontium doping affects the hydration behavior of the cement clinker mineral phase $\mathrm{Ca}_{7} \mathrm{ZrAl}_{6} \mathrm{O}_{18}$, and leads to changes in the hydration products properties. There is a relationship between the proportion of residual unhydrated cement particles and the properties of the particular cement clinker mineral phases involved. After $24 \mathrm{~h}$ of curing at $50{ }^{\circ} \mathrm{C}$, where the hardened cement paste (Sample $\mathrm{C}$ ) consists primarily of $\mathrm{C}_{3} \mathrm{AH}_{6}$, the original $\mathrm{Ca}_{7} \mathrm{ZrAl}_{6} \mathrm{O}_{18}$ cement particles are no longer evident. In the Sr-doping of $\mathrm{Ca}_{7} \mathrm{ZrAl}_{6} \mathrm{O}_{18}$ case, there is inhibition of hydration, and the $\mathrm{Sr}_{1.25} \mathrm{Ca}_{5.75} \mathrm{ZrAl}_{6} \mathrm{O}_{18}$ cementitious particles exist in the hardened cement paste up to $72 \mathrm{~h}$ (Sample A). This material would need to cure over $72 \mathrm{~h}$ to reach complete hydration. Hence, XRD data for $0.5 \mathrm{~h}-7 \mathrm{~d}$ materials containing strontium indicates the appearance of additional peaks adjacent to each of the reference $\mathrm{C}_{3} \mathrm{AH}_{6}$ lines caused by the presence of an additional Sr-rich cubic phase. These results confirmed the strontium retention by calcium zirconium aluminate cement paste through the chemical bonding to $\mathrm{C}-\mathrm{A}-\mathrm{H}$ in the hydrated phase. The presence 
of strontium in the C-A-H matrix is also known to delay the transformation of hexagonal hydrates into the cubic phases.

\subsection{Ex-Situ ${ }^{27}$ Al NMR Study of the Hydration Reaction at $50{ }^{\circ} \mathrm{C}$}

Figure $4 \mathrm{a}$, b presents the ${ }^{27} \mathrm{Al}$ NMR spectra of synthesized $\mathrm{Ca}_{7} \mathrm{ZrAl}_{6} \mathrm{O}_{18}$ and Sr-doped $\mathrm{Ca}_{7} \mathrm{ZrAl}_{6} \mathrm{O}_{18}$ cements together with their products of hydration. The ${ }^{27} \mathrm{Al}$ MASNMR spectra of the starting unhydrated samples are shown by the red lines. The intense and broad peak at ca. $50 \mathrm{ppm}$ is due to $\mathrm{Ca}_{7} \mathrm{ZrAl}_{6} \mathrm{O}_{18}$, which consists of orientationally disordered six $\mathrm{AlO}_{4}$ tetrahedra linked together by sharing corners, to form $\left[\mathrm{Al}_{6} \mathrm{O}_{18}\right]$ rings [29]. The ${ }^{27} \mathrm{Al}$ MAS NMR spectra of the hydrated samples during the first $15 \mathrm{~min}$ all contain peaks near $4 \mathrm{ppm}$ due to ${ }^{\mathrm{VI}} \mathrm{Al}$ in the cement hydration reaction products (amorphous or poorly crystalline hexagonal hydrates $\mathrm{C}_{4} \mathrm{AH}_{19}$ or $\mathrm{C}_{2} \mathrm{AH}_{8}$ ) (Figure $4 \mathrm{a}, \mathrm{b}$ ).

a) hydrated $\mathrm{Ca}_{7} \mathrm{ZrAl}_{6} \mathrm{O}_{18}$ cement

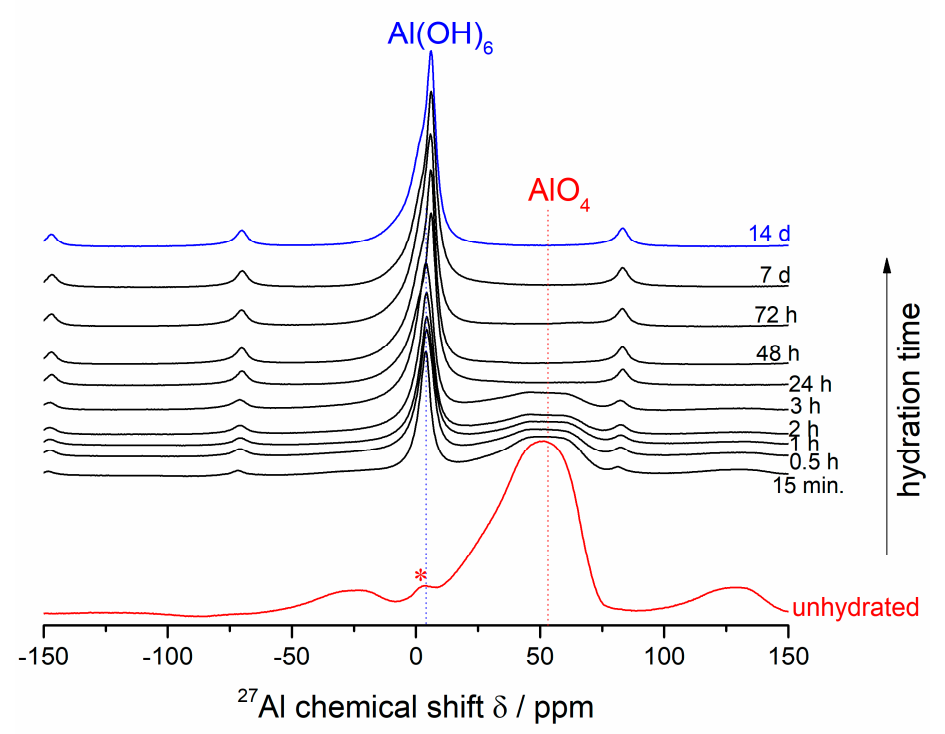

b) hydrated $\mathrm{Sr}_{1.25} \mathrm{Ca}_{5.75} \mathrm{ZrAl}_{6} \mathrm{O}_{18}$ cement

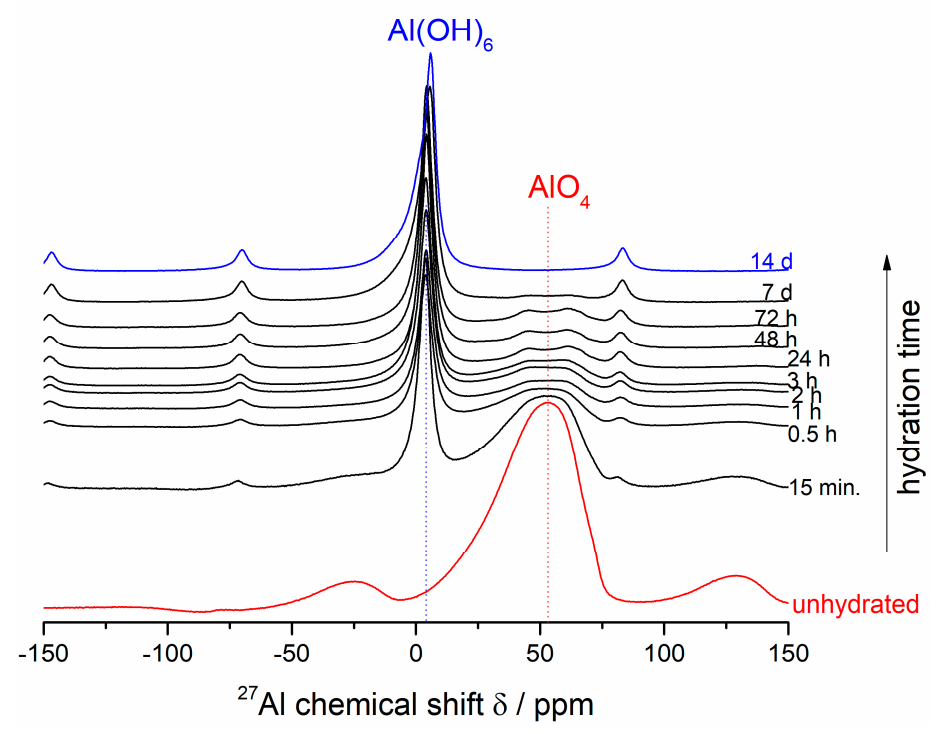

Figure 4. Cont. 


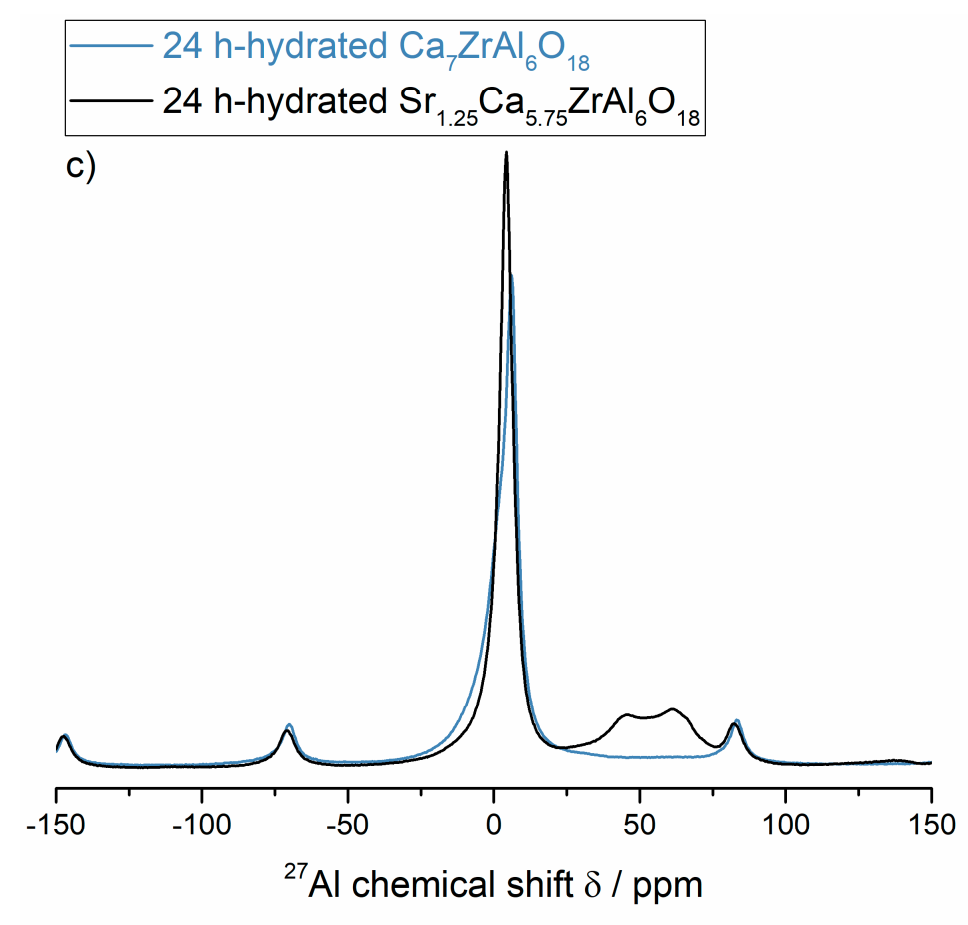

d) hydrated $\mathrm{Ca}_{7} \mathrm{ZrAl}_{6} \mathrm{O}_{18}$ cement

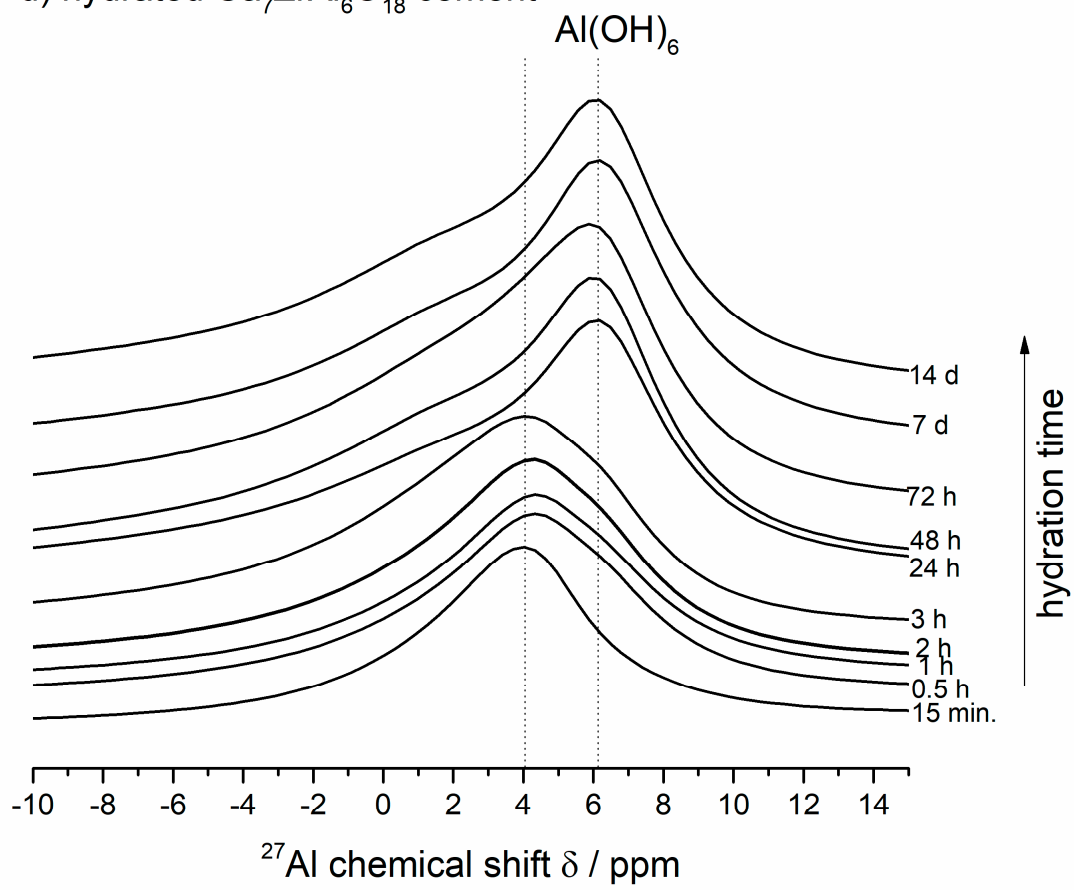

Figure 4. Cont. 


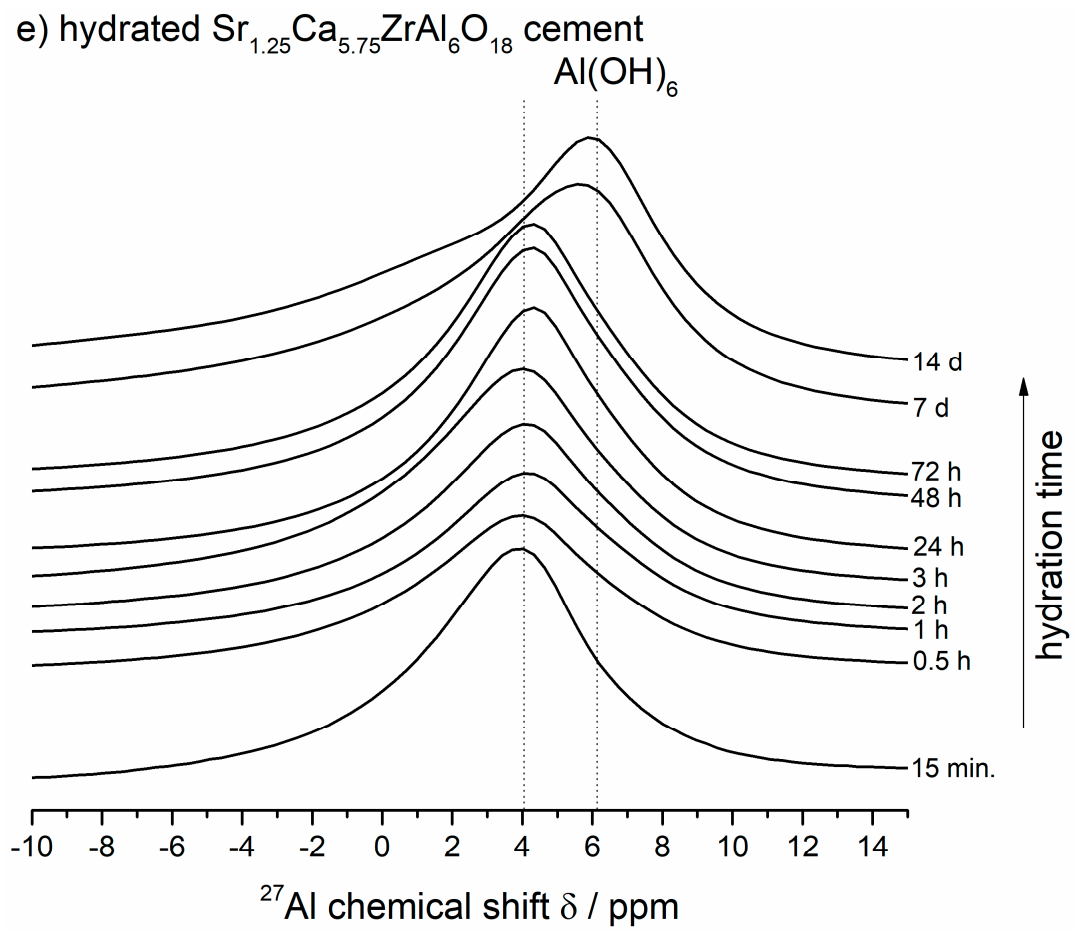

Figure 4. (a,b) The room-temperature ${ }^{27} \mathrm{Al}$ MASNMR spectra of unhydrated $\mathrm{Ca}_{7} \mathrm{ZrAl}_{6} \mathrm{O}_{18}$ (Sample C) and $\mathrm{Sr}_{1.25} \mathrm{Ca}_{5.75} \mathrm{ZrAl}_{6} \mathrm{O}_{18}$ (Sample A) cements, and their products of hydration formed between $15 \mathrm{~min}$ and $14 \mathrm{~d}$ at $50{ }^{\circ} \mathrm{C}$. The arrow means the changes according to the direction of increasing hydration time. (c) A comparison of NMR spectra of both cements at $24 \mathrm{~h}$ of hydration. (d,e) The lines at ca. 4-6 ppm for octahedrally coordinated lattice $\mathrm{Al}^{3+}$ in calcium aluminate hydrates.

For the partially reacted samples, the signals are in the ca. $4 \mathrm{ppm}$ and ca. $46-61 \mathrm{ppm}$ ranges due to both hydrates and unhydrated reactants, respectively (Figure 4c). For the totally hydrated (and converted) samples, all of the signalsarein the ca. $6 \mathrm{ppm}$ range, consistent with total conversion of $\mathrm{Al}$ from tetrahedral coordination in the unhydrated $\mathrm{Ca}_{7} \mathrm{ZrAl}_{6} \mathrm{O}_{18}$ and $\mathrm{Sr}_{1.25} \mathrm{Ca}_{5.75} \mathrm{ZrAl}_{6} \mathrm{O}_{18}$ cements to octahedral coordination [19] in the final hydrates formed at $24 \mathrm{~h}$ (undoped cement) or $7 \mathrm{~d}$ (Sr-doped cement), as expected from previous works on the calcium aluminate cement hydration processes investigated by solid-state ${ }^{27} \mathrm{Al}$ MAS NMR studies $[19,25]$. The maximum for the ${ }^{\mathrm{VI}} \mathrm{Al}$ peak alters slightly depending on the calcium aluminate hydrates present $[18,19]$. For the undoped $\mathrm{Ca}_{7} \mathrm{ZrAl}_{6} \mathrm{O}_{18}$ cement hydrated between $15 \mathrm{~min}$ and $3 \mathrm{~h}$, in which the detected crystalline hydrates are mainly hexagonal phases, the peak maximum is at ca. 4 ppm and shifts to $6 \mathrm{ppm}$ for this cement hydrated between $24 \mathrm{~h}$ and $14 \mathrm{~d}$ (Figure $4 \mathrm{~d}$ ), which by XRD contain cubic $\mathrm{C}_{3} \mathrm{AH}_{6}$ as the predominant phase. This type of shift is delayed up to $7 \mathrm{~d}$ in the hydrated Sr-doped cement (Figure 4e), where Ca-rich $(\mathrm{Sr}, \mathrm{C})_{3} \mathrm{AH}_{6}$ or pure $\mathrm{C}_{3} \mathrm{AH}_{6}$ begin to form. Hence, it can be summarized that the chemical shift occurring at ca. $4 \mathrm{ppm}$ was due to octahedrally coordinated framework aluminum atoms in Sr-rich $(\mathrm{Sr}, \mathrm{C})_{3} \mathrm{AH}_{6}\left(\mathrm{Sr}_{1.25} \mathrm{Ca}_{5.75} \mathrm{ZrAl}_{6} \mathrm{O}_{18}\right.$ cement paste), poorly crystalline $\mathrm{C}_{3} \mathrm{AH}_{6}\left(\mathrm{Ca}_{7} \mathrm{ZrAl}_{6} \mathrm{O}_{18}\right.$ cement paste) and hexagonal hydrates (both cement pastes) formed at an early stage of hydration. The chemical shift occurring at ca. $6 \mathrm{ppm}$ was due to octahedrally coordinated framework aluminum atoms in Ca-rich $(\mathrm{Sr}, \mathrm{C})_{3} \mathrm{AH}_{6}$ or pure $\mathrm{C}_{3} \mathrm{AH}_{6}$ formed in the totally reacted Sr-doped sample, as it can be referenced in for pure $\mathrm{C}_{3} \mathrm{AH}_{6}$ formed in the reference fully hydrated and converted undoped cement paste. It is worth discussing that the maximum for the $\mathrm{Al}(6)$ peak belonging to $\mathrm{C}-\mathrm{A}-\mathrm{H}$ phases varies slightly from data presented in Ref. $[18,19]$. In those works, and many others, the peak maximum belonging to $\mathrm{C}_{3} \mathrm{AH}_{6}$ was located at about $12 \mathrm{ppm}$, whereas the peak maxima belonging to hexagonal hydrates were located at ca. $10-11 \mathrm{ppm}$. 


\subsection{Microstructural Studies on the Hydrated $\mathrm{Sr}_{1.25} \mathrm{Ca}_{5.75} \mathrm{ZrAl}_{6} \mathrm{O}_{18}$ Cement Paste}

The development of $\mathrm{Sr}_{1.25} \mathrm{Ca}_{5.75} \mathrm{ZrAl}_{6} \mathrm{O}_{18}$ cement paste microstructure in time can directly be linked to the evolution of phase composition presented in Sections 3.1 and 3.2. Figure 5 shows the typical microstructure of this cement paste fragment after $24 \mathrm{~h}$ hydration at $50{ }^{\circ} \mathrm{C}$. The presence of $\mathrm{Sr}$ in $\mathrm{Sr}_{1.25} \mathrm{Ca}_{5.75} \mathrm{ZrAl}_{6} \mathrm{O}_{18}$ clinker affects formation of Sr-rich $(\mathrm{Sr}, \mathrm{C})_{3} \mathrm{AH}_{6}$ (Figure 5a-point 1) with a cubic/isometric crystal form [30,31]. The EDS spectrum presenting intensity vs. energy of the detected $\mathrm{X}$-ray clearly identifies the peaks of $\mathrm{Sr}, \mathrm{Ca}, \mathrm{Al}$ and $\mathrm{O}$ (Figure $5 \mathrm{~b}$ ). The EDS spectrum from the hexagonal irregular flakes is shown in Figure $5 \mathrm{c}$. The $\mathrm{Ca}, \mathrm{Al}$ and $\mathrm{O}$ peaks are mainly due to $\mathrm{C}-\mathrm{A}-\mathrm{H}$ phases. EDS intensity ratio of calcium and aluminum peaks indicates the presence of $\mathrm{C}_{4} \mathrm{AH}_{19}$ hydrate rather than $\mathrm{C}_{2} \mathrm{AH}_{8}$ hydrate.

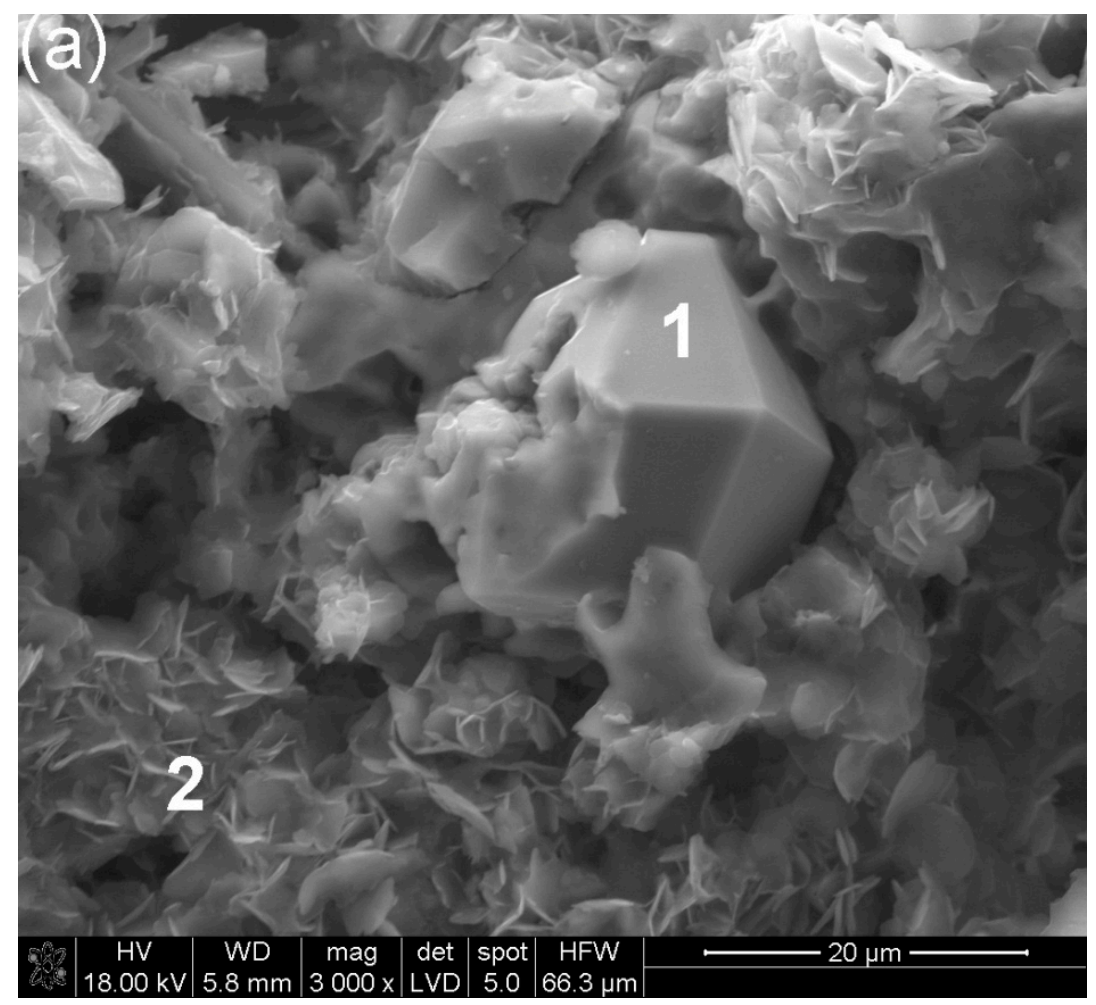

(b)

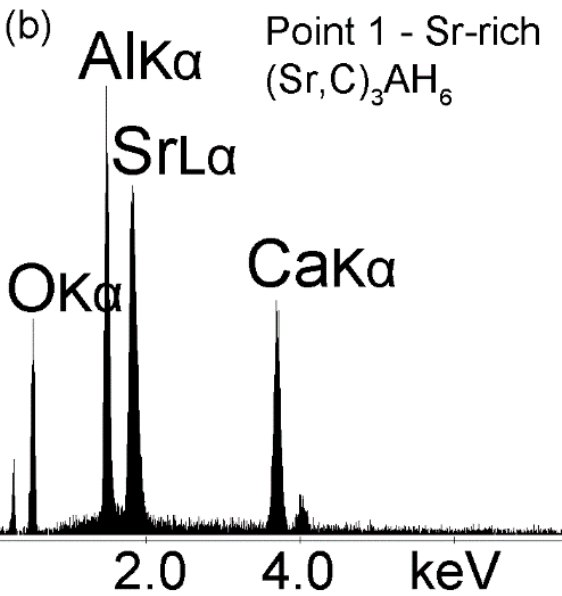

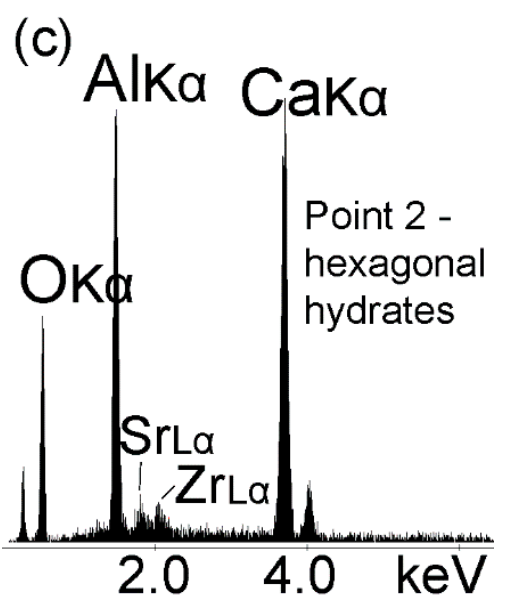

Figure 5. SEM image of the hydrated $\mathrm{Sr}_{1.25} \mathrm{Ca}_{5.75} \mathrm{ZrAl}_{6} \mathrm{O}_{18}$ cement (Sample A) at the age of $24 \mathrm{~h}$ (a). Spot 1-2 EDS analysis; $(\mathbf{b}, \mathbf{c})$ EDS spectra of the sample in the microarea $1\left(\mathrm{Sr}\right.$-rich $\left.(\mathrm{Sr}, \mathrm{C})_{3} \mathrm{AH}_{6}\right)$ and 2 (hexagonal calcium aluminate hydrates), respectively. 
Most of the $\mathrm{C}_{3} \mathrm{AH}_{6}$ or Ca-rich $(\mathrm{Sr}, \mathrm{C})_{3} \mathrm{AH}_{6}$ crystals formed after a hydration time of $7 \mathrm{~d}$ attain the shape of cubes, pyritohedra or other more complex forms of the isometric system, which are reinforced with $\mathrm{Al}(\mathrm{OH})_{3}$ crystals (Figure 6a,c). As observed before, those hydration products are strongly dependent on curing time and the Ca peak (Figure 6b) intensity increases relative to the $\mathrm{Sr}$ peak intensity (Figure 5b). Hence, as the curing time increases, the crystals belonging to a cubic or isometric system formed initially as a transient $\mathrm{Sr}$-rich $(\mathrm{Sr}, \mathrm{C})_{3} \mathrm{AH}_{6}$ were replaced with $\mathrm{Ca}-\mathrm{rich}$ $(\mathrm{Sr}, \mathrm{C})_{3} \mathrm{AH}_{6}$ or pure $\mathrm{C}_{3} \mathrm{AH}_{6}$. An unavoidable change of one form of calcium aluminate hydrate to another can be found elsewhere [32-34].

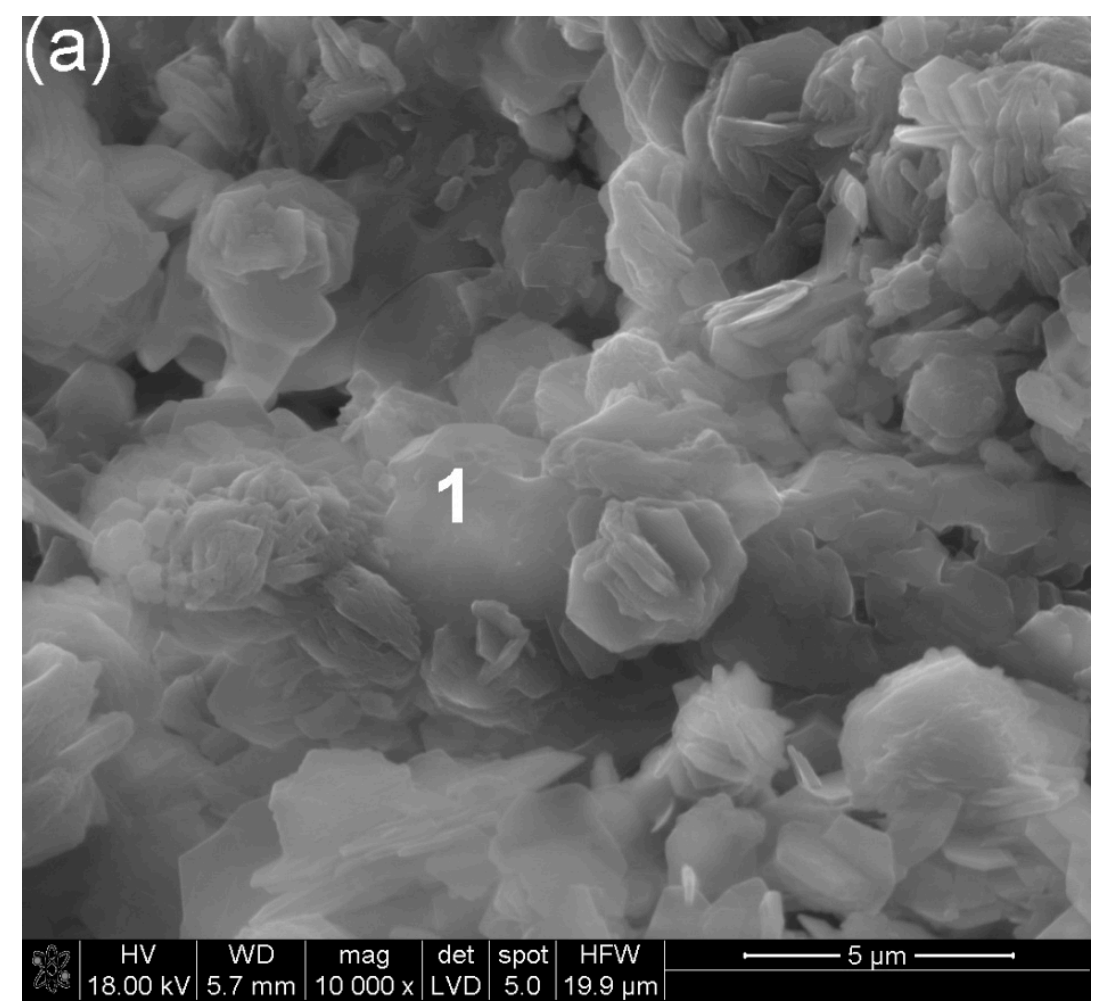

(b)

Point 1 - Ca-rich

$\mathrm{OKa} \quad(\mathrm{Sr}, \mathrm{C})_{3} \mathrm{AH}_{6}$

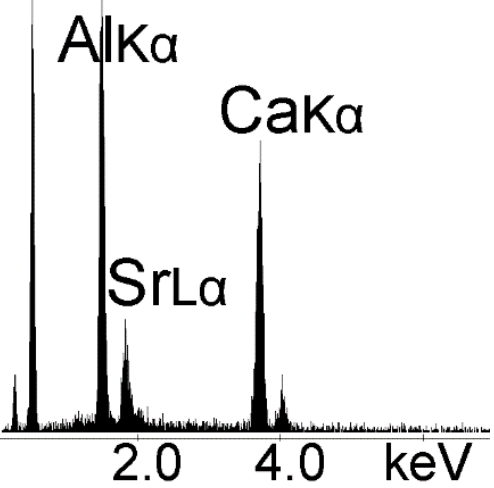

Figure 6. Cont. 


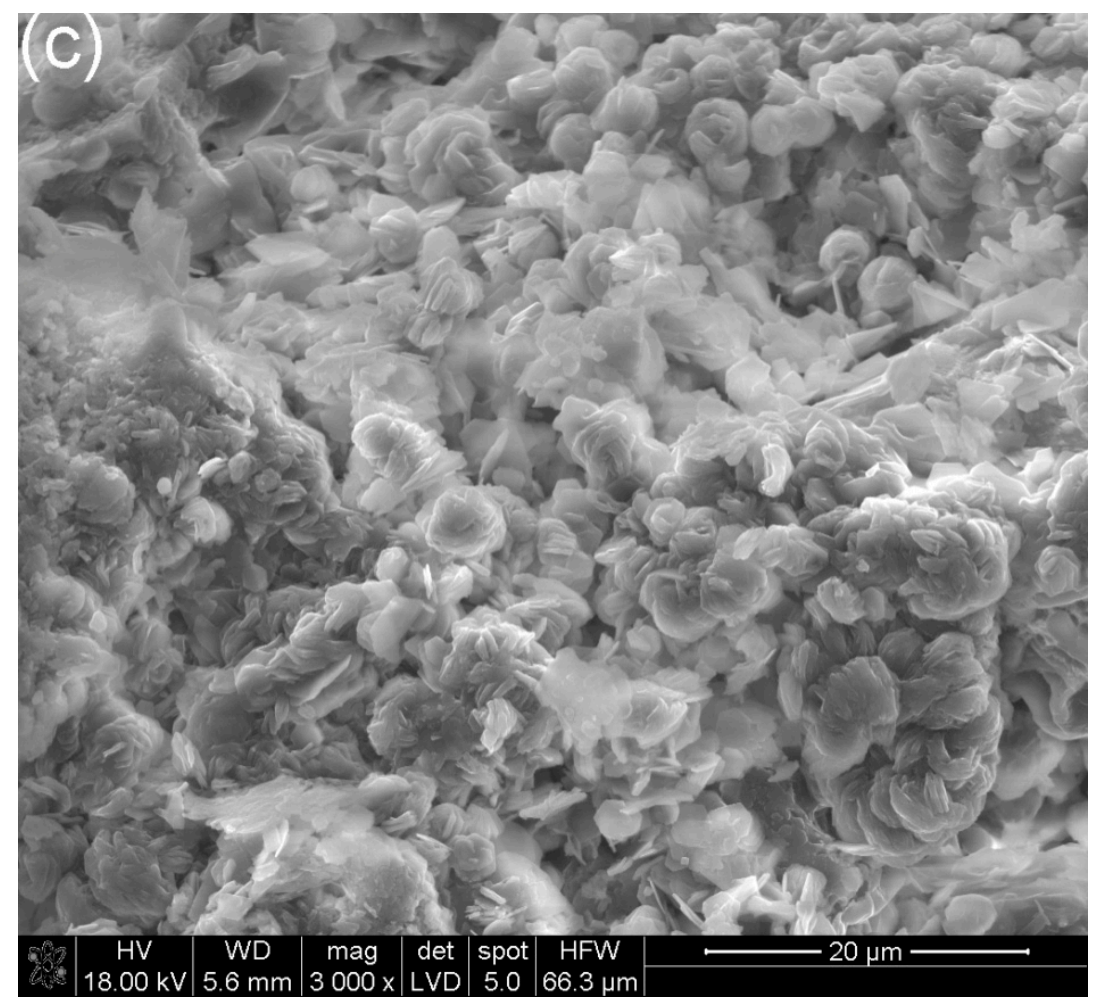

Figure 6. SEM image of the hydrated $\mathrm{Sr}_{1.25} \mathrm{Ca}_{5.75} \mathrm{ZrAl}_{6} \mathrm{O}_{18}$ cement (Sample A) at the age of $7 \mathrm{~d}$ (a). Spot 1 EDS analysis; (b) EDS spectrum of the sample in the microarea $1-$ Ca-rich $(\mathrm{Sr}, \mathrm{C})_{3} \mathrm{AH}_{6}$; (c) overview of microstructure.

\section{Conclusions}

According to the current research, many conclusions can be drawn:

(1) The Sr-doped cement is developed through structural substitution for Ca ions by Sr ions in the $\mathrm{Ca}_{7} \mathrm{ZrAl}_{6} \mathrm{O}_{18}$ clinker phase.

(2) Strontium was used as a retarding agent to block this cement clinker phase hydration at a curing temperature of $50{ }^{\circ} \mathrm{C}$. Hence, the residual unhydrated cement particles in the hardened $\mathrm{Sr}_{1.25} \mathrm{Ca}_{5.75} \mathrm{ZrAl}_{6} \mathrm{O}_{18}$ cement paste were present for much longer than for the undoped $\mathrm{Ca}_{7} \mathrm{ZrAl}_{6} \mathrm{O}_{18}$ clinker phase sample as it was observed by XRD.

(3) The hydration of both $\mathrm{Ca}_{7} \mathrm{ZrAl}_{6} \mathrm{O}_{18}$ and $\mathrm{Sr}_{1.25} \mathrm{Ca}_{5.75} \mathrm{ZrAl}_{6} \mathrm{O}_{18}$ cements was also inspected using the ${ }^{27} \mathrm{Al}$ MAS NMR technique. This hydration is accompanied by a change of Al-coordination from tetrahedral to octahedral. This complete conversion from anhydrous ${ }^{27} \mathrm{Al}^{\mathrm{IV}}$ to hydrated ${ }^{27} \mathrm{Al}^{\mathrm{VI}}$ species was achieved during the first $24 \mathrm{~h}$ of hydration at $50{ }^{\circ} \mathrm{C}$ for $\mathrm{Ca}_{7} \mathrm{ZrAl}_{6} \mathrm{O}_{18}$ and during $7 \mathrm{~d}$ of hydration at $50{ }^{\circ} \mathrm{C}$ for $\mathrm{Sr}_{1.25} \mathrm{Ca}_{5.75} \mathrm{ZrAl}_{6} \mathrm{O}_{18}$.

(4) The hexagonal phases were formed starting in the very first minutes of hydration of these cements. For each cement type tested, these unstable hydrates consist mainly of $\mathrm{C}_{4} \mathrm{AH}_{19}$ and probably of $\mathrm{C}_{2} \mathrm{AH}_{8}$ as it was observed by XRD.

(5) The formation of a thermodynamically stable phase pure $\mathrm{C}_{3} \mathrm{AH}_{6}$ or Ca-rich $(\mathrm{Sr}, \mathrm{C})_{3} \mathrm{AH}_{6}$ in the hardened $\mathrm{Sr}_{1.25} \mathrm{Ca}_{5.75} \mathrm{ZrAl}_{6} \mathrm{O}_{18}$ cement paste was preceded by that of a number of less stable phases, i.e.,Sr-rich $(\mathrm{Sr}, \mathrm{C})_{3} \mathrm{AH}_{6}$ hydrate and other hexagonal $\mathrm{Ca}-\mathrm{Al}$ hydrates. The Sr-rich $(\mathrm{Sr}, \mathrm{C})_{3} \mathrm{AH}_{6}$ hydrate existing between $0.5 \mathrm{~h}$ and $7 \mathrm{~d}$ of curing was isostructural with the Ca-rich $(\mathrm{Sr}, \mathrm{C})_{3} \mathrm{AH}_{6}$ or pure $\mathrm{C}_{3} \mathrm{AH}_{6}$ formed at the age of $7 \mathrm{~d}$.

(6) The transformation of the hexagonal calcium aluminate hydrates and $\mathrm{Sr}$-rich $(\mathrm{Sr}, \mathrm{C})_{3} \mathrm{AH}_{6}$ hydrate into the cubic phase Ca-rich $(\mathrm{Sr}, \mathrm{C})_{3} \mathrm{AH}_{6}$ or pure $\mathrm{C}_{3} \mathrm{AH}_{6}$ was expressed in terms of chemical shift from ca. 4 ppm to ca. $6 \mathrm{ppm}$ in the hardened $\mathrm{Sr}_{1.25} \mathrm{Ca}_{5.75} \mathrm{ZrAl}_{6} \mathrm{O}_{18}$ cement paste at the age of $7 \mathrm{~d}$. 
The same ${ }^{27} \mathrm{Al}$ NMR chemical shift was detected at the age of $24 \mathrm{~h}$ for the reference hardened $\mathrm{Ca}_{7} \mathrm{ZrAl}_{6} \mathrm{O}_{18}$ cement paste.

Funding: This project was financed by the National Science Centre, Poland, project number 2017/26/D/ST8/00012 (Recipient: D. Madej). The sponsor had no role in the design, execution, interpretation, or writing of the study.

Conflicts of Interest: The author declares no conflicts of interest.

\section{Nomenclature}

$\begin{array}{ll}\mathrm{C} & \mathrm{CaO} \\ \mathrm{A} & \mathrm{Al}_{2} \mathrm{O}_{3} \\ \mathrm{Z} & \mathrm{ZrO}_{2} \\ \mathrm{Sr} & \mathrm{SrO} \\ \mathrm{H} & \mathrm{H}_{2} \mathrm{O}\end{array}$

\section{References}

1. Nowacka, M.; Pacewska, B. Effect of structurally different aluminosilicates on early-age hydration of calcium aluminate cement depending on temperature. Constr. Build. Mater. 2020, 235, 117404. [CrossRef]

2. Cao, Y.-F.; Tao, Z.; Pan, Z.; Wuhrer, R. Effect of calcium aluminate cement on geopolymer concrete cured at ambient temperature. Constr. Build. Mater. 2018, 191, 242-252. [CrossRef]

3. Zhang, X.; He, Y.; Lu, C.; Huang, Z. Effects of sodium gluconate on early hydration and mortar performance of Portland cement-calcium aluminate cement-anhydrite binder. Constr. Build. Mater. 2017, 157, 1065-1073. [CrossRef]

4. Madej, D. Synthesis, formation mechanism and hydraulic activity of novel composite cements belonging to the system $\mathrm{CaO}-\mathrm{Al}_{2} \mathrm{O}_{3}-\mathrm{ZrO}_{2}$. J. Therm. Anal. Calorim. 2017, 130, 1913-1924. [CrossRef]

5. Litwinek, E.; Madej, D. Structure, microstructure and thermal stability characterizations of $\mathrm{C}_{3} \mathrm{AH}_{6}$ synthesized from different precursors through hydration. J. Therm. Anal. Calorim. 2019. [CrossRef]

6. Madej, D.; Rajska, M.; Kruk, A. Synthesis and hydration behaviour of calcium zirconium aluminate powders by modifying co-precipitation method. Ceram. Int. 2020, 46, 2373-2383. [CrossRef]

7. Madej, D. A new implementation of electrochemical impedance spectroscopy (EIS) and other methods to monitor the progress of hydration of strontium monoaluminate $\left(\mathrm{SrAl}_{2} \mathrm{O}_{4}\right)$ cement. J. Therm. Anal. 2019, 139, 17-28. [CrossRef]

8. Liu, K.; Chen, A.; Shang, X.; Chen, L.; Zheng, L.; Gao, S.; Zhou, Y.; Wang, Q.; Ye, G. The impact of mechanical grinding on calcium aluminate cement hydration at $30^{\circ} \mathrm{C}$. Ceram. Int. 2019, 45, 14121-14125. [CrossRef]

9. Kerienè, J.; Antonovič, V.; Stonys, R.; Boris, R. The influence of the ageing of calcium aluminate cement on the properties of mortar. Constr. Build. Mater. 2019, 205, 387-397. [CrossRef]

10. Garcia-Lodeiro, I.; Irisawa, K.; Jin, F.; Meguro, Y.; Kinoshita, H. Reduction of water content in calcium aluminate cement with/out phosphate modification for alternative cementation technique. Cem. Concr. Res. 2018, 109, 243-253. [CrossRef]

11. Madej, D.; Szczerba, J.; Nocuń-Wczelik, W.; Gajerski, R. Hydration of $\mathrm{Ca}_{7} \mathrm{ZrAl}_{6} \mathrm{O}_{18}$ phase. Ceram. Int. 2012, 38, 3821-3827. [CrossRef]

12. Madej, D.; Boris, R. Synthesis, characterization and hydration analysis of $\mathrm{Ba}^{2+}-, \mathrm{Cu}^{2+}-$ or $\mathrm{Bi}^{3+}-\mathrm{doped}$ $\mathrm{CaO}-\mathrm{Al}_{2} \mathrm{O}_{3}-\mathrm{ZrO}_{2}$-based cements. J. Therm. Anal. Calorim. 2019, 138, 4331-4340. [CrossRef]

13. Madej, D. Hydration, carbonation and thermal stability of hydrates in $\mathrm{Ca}_{7-\mathrm{x}} \mathrm{Sr}_{\mathrm{x}} \mathrm{ZrAl}_{6} \mathrm{O}_{18}$ cement. J. Therm. Anal. Calorim. 2018, 131, 2411-2420. [CrossRef]

14. Pöllmann, H.; Kaden, R. Mono- (strontium-, calcium-) aluminate based cements. In Calcium Aluminates Proceedings of the International Conference; Building Research Establishment: Watford, UK, 2014; pp. 99-108.

15. Ukrainczyk, N.; Vrbos, N.; Šipušić, J. Influence of metal chloride salts on calcium aluminate cement hydration. Adv. Cem. Res. 2012, 24, 249-262. [CrossRef]

16. Duran, A.; Sirera, R.; Nicolas, M.P.; Navarro-Blasco, I.; Fernández, J.M.; Alvarez, J.I. Study of the early hydration of calcium aluminates in the presence of different metallic salts. Cem. Concr. Res. 2016, 81, 1-15. [CrossRef] 
17. Faucon, P.; Charpentier, T.; Bertrandie, D.; Nonat, A.; Virlet, J.; Petit, J.C. Characterization of calcium aluminate hydrates and related hydrates of cement pastes by ${ }^{27} \mathrm{Al}$ MQ-MAS NMR. Inorg. Chem. 1998, 37, 3726-3733. [CrossRef]

18. Skibsted, J.; Henderson, E.; Jakobsen, H.J. Characterization of calcium aluminate phases in cements by ${ }^{27} \mathrm{Al}$ MAS NMR spectroscopy. Inorg. Chem. 1993, 32, 1013-1027. [CrossRef]

19. Cong, X.; Kirkpatrick, R.J. Hydration of calcium aluminate cements: A solid-state ${ }^{27} \mathrm{Al}$ NMR study. J. Am. Ceram. Soc. 1991, 76, 409-416. [CrossRef]

20. Mercury, J.M.R.; Pena, P.; de Aza, A.H.; Turrillas, X.; Sobrados, I.; Sanz, J. Solid-state ${ }^{27}$ Al and ${ }^{29}$ Si NMR investigations on Si-substituted hydrogarnets. Acta Mater. 2007, 55, 1183-1191. [CrossRef]

21. Myers, R.J.; Bernal, S.A.; Gehman, J.D.; Van Deventer, J.S.J.; Provis, J. The role of Al in cross-linking of alkali-activated slag cements. J. Am. Ceram. Soc. 2014, 98, 996-1004. [CrossRef]

22. Walkley, B.; Provis, J.L. Solid-state nuclear magnetic resonance spectroscopy of cements. Mater. Today Adv. 2019, 1, 100007. [CrossRef]

23. Müller, D.; Rettel, A.; Gessner, W.; Scheler, G. An application of solid state magic-angle spinning ${ }^{27} \mathrm{Al} \mathrm{NMR}$ to the study of cement hydration. J. Magn. Reson. 1984, 57, 152-156. [CrossRef]

24. Muller, D.; Gessner, W.; Samoson, A.; Lippmaa, E.; Scheler, G. Solid state ${ }^{27}$ Al NMR studies of polycrystalline aluminates in the system $\mathrm{CaO}-\mathrm{Al}_{2} \mathrm{O}_{3}$. Polyhedron 1986, 5, 779-785. [CrossRef]

25. Hughes, C.E.; Walkley, B.; Gardner, L.; Walling, S.A.; Bernal, S.A.; Iuga, D.; Provis, J.; Harris, K.D.M. Exploiting in-situ solid-state NMR spectroscopy to probe the early stages of hydration of calcium aluminate cement. Solid State Nucl. Magn. Reson. 2019, 99, 1-6. [CrossRef] [PubMed]

26. Garces, P.; Alcocel, E.; Chinchon, S.; Andreu, C.; Alcaide, J. Alcaide, Effect of curing temperature in some hydration characteristics of calcium aluminate cement compared with those of portland cement. Cem. Concr. Res. 1997, 27, 1343-1355. [CrossRef]

27. Zhang, Y.; Ye, G.; Gu, W.; Ding, D.; Chen, L.; Zhu, L. Conversion of calcium aluminate cement hydrates at $60{ }^{\circ} \mathrm{C}$ with and without water. J. Am. Ceram. Soc. 2018, 101, 2712-2717. [CrossRef]

28. Luz, A.P.; Pandolfelli, V.C. Halting the calcium aluminate cement hydration process. Ceram. Int. 2011, 37 , 3789-3793. [CrossRef]

29. Fukuda, K.; Iwata, T.; Nishiyuki, K. Crystal structure, structural disorder, and hydration behavior of calcium zirconium aluminate, $\mathrm{Ca}_{7} \mathrm{ZrAl}_{6} \mathrm{O}_{18}$. Chem. Mater. 2007, 19, 3726-3731. [CrossRef]

30. Das, S.K.; Kumar, S.K.; Das, P.K. Crystal morphology of calcium aluminates hydrated for 14 days. J. Mater. Sci. Lett. 1997, 16, 735-736. [CrossRef]

31. Kumar, S.; Das, S.K.; Daspoddar, P.K. Microstructure of calcium aluminates and their mixes after 3 days of hydration. Trans. Indian Ceram. Soc. 1999, 58, 115-117. [CrossRef]

32. Antonovič, V.; Keriené, J.; Boris, R.; Aleknevičius, M. The effect of temperature on the formation of the hydrated calcium aluminate cement structure. Procedia Eng. 2013, 57, 99-106. [CrossRef]

33. López, A.H.; Calvo, J.L.G.; Olmo, J.G.; Petit, S.; Alonso, M.C. Microstructural evolution of calcium aluminate cements hydration with silica fume and fly ash additions by scanning electron microscopy, and mid and near-infrared spectroscopy. J. Am. Ceram. Soc. 2008, 91, 1258-1265. [CrossRef]

34. Rashid, S.; Barnes, P.; Bensted, J.; Turrillas, X. Conversion of calcium aluminate cement hydrates re-examined with synchrotron energy-dispersive diffraction. J. Mater. Sci. Lett. 1994, 13, 1232-1234. [CrossRef]

(C) 2020 by the author. Licensee MDPI, Basel, Switzerland. This article is an open access article distributed under the terms and conditions of the Creative Commons Attribution (CC BY) license (http://creativecommons.org/licenses/by/4.0/). 